\title{
PENERAPAN APLIKASI PENDAFTARAN ANTRIAN PASPOR ONLINE (APAPO) DALAM PERSPEKTIF E-GOVERNMENT
}

\author{
Nurrizha A. Charani, Tri Putra Adi, dan Diba H. Latifa \\ FISIP Universitas Muhammadiyah Malang, Jl. Raya Tlogomas, Kota Malang
}

\begin{abstract}
Public service is an obligation for the government to provide the best possible service to the community. The government is obliged to provide services that are needed so that it can increase the public's sense of trust in the government. Currently, it is often felt that the quality of service is minimal and far from the expectations of the community. This study aims to analyze passport services using the Online Passport Registration Application (APAPO) at the Class I Immigration Office in Malang City. The results showed that the existence of APAPO is the implementation of a bureaucratic reform in the Class I Immigration Office Malang in order to improve the quality of public services. This online application really helps people to be more effective in making passports because it saves time and money.
\end{abstract}

\begin{abstract}
Abstrak: Pelayanan publik merupakan kewajiban bagi pemerintah untuk memberikan pelayanan yang sebaik-baiknya kepada masyarakat. Pemerintah wajib menyediakan pelayanan yang sangat dibutuhkan sehingga dapat meningkatkan rasa kepercayaan masyarakat terhadap pemerintah. Saat ini masih sering dirasakan bahwa kualitas pelayanan minim dan masih jauh dari harapan masyarakat. Penelitian ini bertujuan untuk menganalisis pelayanan paspor yang menggunakan Aplikasi Pendaftaran Antrian Paspor Online (APAPO) di Kantor Imigrasi Kelas I Kota Malang. Hasil penelitian menunjukkan bahwa keberadaan APAPO merupakan penerapan suatu reformasi birokrasi di Kantor Imigrasi Kelas I Kota Malang guna meningkatkan kualitas pelayanan publik. Aplikasi online ini sangat membatu masyarakat untuk lebih efektif dalam membuat paspor karena menghemat waktu dan biaya.
\end{abstract}

Kata Kunci: APAPO, pelayanan publik, e-goverment, reformasi birokrasi

\section{PENDAHULUAN}

Pelayanan publik telah menjadi kebutuhan masyarakat dalam kehidupan sosial di negara modern. Kebutuhan pelayanan publik akan melibatkan dua aktor, yaitu negara sebagai penyedia pelayanan publik dan individu warga negara sebagai penerima yang menikmati pelayanan publik. Oleh sebab itu, pelayanan publik memberikan cerminan hubungan antara sebuah negara dengan warga negaranya. Tuntutan publik pun akhirnya mengharuskan pemerintah untuk melakukan reformasi pelayanan publik. Caranya dengan meningkatkan mutu dan kinerja pelayanan publik serta pemberian pelayanan secara menyeluruh. Sehingga dapat memberikan kepuasan terhadap semua pihak tanpa adanya diskriminasi. Dalam meningkatkan kualitas pelayanan publik, perlu melakukan usaha pengembangan yang berbasis teknologi dan informasi ke dalam aspek pemerintahan. Salah satunya dengan menghadirkan suatu alat yang biasa dikenal dengan istilah electronic government atau biasa disingkat e-government.
Pengimplementasian e-government sudah banyak diterapkan di beberapa wilayah di dunia, tak terkecuali di Indonesia. E-government ialah suatu bentuk aplikasi pengerjaan tugas dan tata pelaksaanaan pemerintahan dengan menggunakan bantuan teknologi telematika atau teknologi informasi dan komunikasi Indrajit (2012). Pengembangan dan pemanfaatan e-government sudah menjadi salah satu upaya pendukung berbasis elektronik terhadap kinerja pemerintah. Hal tersebut guna menyelenggarakan dan meningkatkan kualitas layanan yang diberikan kepada masyarakat menjadi lebih efektif dan efisien. Sesungguhnya strategi pengintegrasian akan teknologi dan informasi, terutama penggunaan internet dalam mencakup segala bentuk aspek kegiatan dan aktivitas pemerintahan sudah lama diterapkan oleh negara-negara maju dan kaya raya. Pengembangan e-government disuatu wilayah dapat dikatakan sudah menjadi suatu kebutuhan baik dari segi pemerintahan maupun bagi masyarakat.

Melalui programe-government, masyarakat 
bisa merasakan layanan permohonan paspor online, visaonline, dan aplikasi pelaporan orang asing dengan mudah. Selain itu, kkhususnya di Kantor Imigrasi seluruh Indonesia sekarang ini ada program Imigrasi E-Gov Pasti Nyata yang memberikan pengawasan terhadap ijin tinggal warga negara asing. Bukan cuma itu, program E-Gov juga memiliki ITAS dan ITAP Online yang bisa membuat masyarakat Indonesia juga dapat memonitor kedatangan dan ijin tinggal warga negara asing. Program Imigrasi E-Gov Pasti Nyata ini diharapkan akan semakin meningkatkan kualitas pelaksanaan tudas dan fungsi imigrasi.

Pengawasan orang asing sebagai salah satu rangkaian kegiatan pada dasarnya telah dimulai dan dilakukan oleh perwakilan Indonesia di luar negeri ketika menerima permohonan visa. Pengawasan selanjutnya dilaksanakan oleh pejabat imigrasi di Tempat Pemeriksaan Imigrasi (TPI), ketika pejabat imigrasi dengan kewenangannya yang otonom memutuskan untuk menolak atau memberikan izin masuk, kemudian diberikan izin tinggal sesuai dengan visa yang dimilikinya. Selanjutnya pengawasan beralih ke kantor imigrasi yang wilayah kerjanya meliputi tempat tinggal orang asing tersebut. Dalam menghadapi implikasi dari kebijakan bebas visa kunjungan, Ditjen Imigrasi melakukan pengawasan keimigrasian yang dilakukan dengan cara:

1. Pengawasan secara administratif, yaitu:

a. Dilakukan pada saat permohonan visa meliputi: pemeriksaan kebenaran penjamin, berkas permohonan, rekomendasi/ izin dari instansi terkait

b. Saat masuk dan keluar wilayah Indonesia meliputi: paspor yang sah dan masih berlaku, visa/izin tinggal, tiket kembali

c. Pemberian dan perpanjangan perijinan keimigrasian di Kantor Imigrasi seluruh Indonesia (121 Kantor Imigrasi) meliputi: pemeriksaan penjamin, pemeriksaan domisili, pemeriksaan kegiatan orang asing, rekomendasi/izin dari instansi terkait.

2. Pengawasan lapangan, yaitu dilakukan dengan melakukan pengecekan terhadap keberadaan dan kegiatan orang asing selama berada di Indonesia meliputi: hotel, tempat hibu- ran, perusahaanperusahaan yang mempekerjakan tenaga kerja asing, dan tempat lain yang diduga terdapat kegiatan orang asing. Selain itu, keimigrasian juga melakukan upaya dalam rangka pengawasan terhadap penyalahgunaan izin oleh orang asing di Indonesia di berbagai sektor khususnya sektor informal, antara lain:

a. Peningkatan pemanfaatan Sistem Informasi Manajemen Keimigrasian yakni Border Control Management (BCM) dan Aplikasi Pelaporan Orang Asing (APOA)

b. Operasi POA (rutin/insidentil) dilakukan oleh Kanim di seluruh Indonesia.

c. Membentuk Sekretariat TIMPORA di Ditjen Imigrasi, kanwil Kemenkumham, dan Kanim seluruh wilayah Indonesia baik di tingkat pusat, provinsi, kabupaten, dan kota.

Di era globalisasi seperti saat ini, tidak heran apabila kemajuan teknologi informasi dan komunikasi dapat menjanjikan efisiensi, kecepatan penyampaian informasi, keterjangkauan, dan transparansi, tidak terkecuali pada pemerintahan. Terlebih, dalam era otonomi daerah saat ini perlu untuk mewujudkan pemerintahan yang baik (good governance) dengan menggunakan teknologi informasi dan komunikasi atau biasa disebut e-government. Melalui e-government pula, peningkatan pelayanan publik dapat terwujud. Seperti yang dikemukakan Dwiyanto (2011) bahwa birokrasi pemerintah dapat mengembangkan penggunaan teknologi informasi dan komunikasi (TIK) dalam pelaksanaan kegiatan pemerintahan, mempermudah interaksi dengan masyarakat, dan mendorong akuntabilitas serta transparansi penyelenggara pelayanan publik.

E-government sangat penting diterapkan pada kondisi saat ini. Namun, hal tersebut harus didukung dengan beberapa hal, yaitu pertama, komitmen pemimpin, hal ini sangat penting untuk mendukung setiap proses dan kegiatan pelayanan publik berbasis elektronik (e-service). Hal tersebut karena pemimpin atau dalam hal ini penyelenggara ataupun pelaksana layanan publik dapat berkomitmen dan mengambil keputusan untuk memberikan pelayanan publik yang prima 
dengan menerapkan e-government. Kedua, sarana dan prasarana, dukungan sarana dan prasarana juga menjadi penting karena tanpa hal tersebut, maka pelayanan berbasis elektronik akan sulit terwujud. Adapun sarana dan prasarana tersebut adalah ketersediaan komputer/ laptop, jaringan internet, dan sebagainya. Ketiga, sumber daya manusia, apabila komitmen pemimpin dan sarana prasarana sudah memadai, namun sumber daya manusia yang dapat mengeksekusi pelayanan berbasis elektronik tidak ada, maka hal tersebut akan sulit terwujud. Dibutuhkan kemampuan sumber daya manusia (pegawai instansi dan sebagainya) diperlukan dalam proses pelaksanaan e-government.

\section{METODE}

Jenis penelitian ini adalah deskriptif kualitatif, yaitu metode yang berdasarkan permasalahan yang dihadapi masyarakat dalam menerima pelayanan yang diberikan pemerintan. Dalam metode eksperimen, ada tiga persyaratan diantarannya yaitu kegiatan mengontrol, kegiatan memanipulasi, dan observasi. Dalam penelitian eksperimen, membagi objek atau subjek yang diteliti menjadi dua kelompok, yaitu kelompok treatment yang mendapatkan perlakuan dan kelompok kontrol yang tidak mendapatkan perlakuan. Sumber data primer, yaitu sumber data yang didapatkan oleh peneliti secara langsung dari subjek atau objek penelitian, misalkan berupa rekaman hasil wawancara. Wawancara yang dilakukan dengan menggunakan pedoman wawancara yang jelas. Sebelum mengadakan wawancara peneliti akan membuat draf pertanyaan serinci mungkin untuk ditanyakan kepada subjek wawancara. Informasi apa yang dibutuhkan, sudah ditulis lengkap dalam draf pertanyaan yang dibuat. Jadi peneliti tidak akan kebingungan mencari pertanyaan yang akan diajukan kepada subjek penelitian. Wawancara dengan jenis seperti ini akan memudahkan proses wawancara, terutama jika peneliti belum begitu ahli dalam melakukan penelitian, disarankan untuk menggunakan teknik wawancara terstruktur, agar data yang didapatkan lengkap. Sehingga akan memudahkan peneliti ketika melakukan analisis data.
Teknik analisis data yang digunakan adalah teknik analisis korelasi. Dalam teknik ini, ada beberapa tahap analisis data, yaitu pertama pengumpulan data. Langkah-langkah penelitian tersebut dijelaskan sebagai berikut: Penelitian korelasi ialah sebuah penelitian yang meliputi kegiatan pengumpulan data, memilih dan menentukan antara hubungan serta tingkat hubungan dua variabel maupun lebih. Penelitian korelasional dapat dilakukan dalam berbagai bidang diantaranya pendidikan, sosial, maupun ekonomi. Penelitian ini hanya terbatas pada panafsiran hubungan antarvariabel saja tidak sampai pada hubungan kausalitas, tetapi penelitian ini dapat dijadikan acuan untuk diajadi penelitian selanjutnya seperti misalanya penelitian eksperimen.

\section{HASIL DAN PEMBAHASAN}

APAPO sebagai aplikasi untuk membuat paspor online sudah berjalan dalam dua versi. Versi pertama telah diluncurkan pada tahun 2017, dan versi kedua dijalankan pada awal tahun 2019 tepat bulan januari. Aplikasi yang dinamakan dengan "APAPO" ini mengalami perbaikan sehingga munculnya versi kedua. APAPO adalah Aplikasi Pendaftaran Antrian Paspor Online.v.2.0. Aplikasi ini dapat di download melalui Google play dan App Store, atau dapat diakses melalui website: antrian. imigrasi.go.id. Dalam aplikasi ini, setiap pemohon dapat melakukan pengajuan permohonan 1 (satu) akun 1x (satu kali) dalam 30 hari. Satu device/ perangkat hanya dapat digunakan untuk 1 (satu) akun.

Masyarakat di Kota Malang umumnya sudah mengetahui perkembangan e-government di bidang pendaftran online dengan cepat dan tepat. Aplikasi ini sangat membantu pelayanan petugas dengan perkembangan e-government ini. Buktinya dalam peluncuran aplikasi ini, masyarakat sudah banyak yang tau dan aplikasi ini selalu dipenuhi pemohon paspor online, pembukaan dilakukan pada hari jumat. Pengecekan yang dilakukan 2 minggu sekali, dan kuota selalu terpenuhi atau pada hari senin dan selasa kuota selalu habis. Melihat dari kuota yang telah ditetapkan mengalami pemenuhan dalam pengisian 
kuota yang telah ditetapkan tadi. Pihak Imigrasi Kota Malang, menetapkan bahwa setiap harinya kuota yang disediakan hanya untuk 150 sampai 200 orang saja.

Cara melakukan aktivasi aplikasi Apapo di gadget:

1. Daftar Akun menggunakan Google Mail / Facebook

2. Isi dan Lengkapi Form Pendaftaran Akun dengan data yang benar

3. Login Akun menggunakan Ussername \& Password yang telah anda buat

4. Klik Antrian Paspor untuk memulai Pendaftaran Antrian Paspor Online

5. Pilih Kantor Imigrasi yang dituju

6. Pilih Jumlah Pemohon \& Waktu kedatangan anda

7. Pilih Jumlah Pemohon \& Waktu kedatangan anda

8. Masukkan Data Pemohonan ( KLIK )

9. Notifikasi berhasil akan muncul setelah anda memasukkan data dengan benar

10.Screenshot Kode Booking / Barcode

Dampak positif dari peluncuran aplikasi

“APAPO” menurut Ibu Vina Pranindya selaku

Kepala Sub-Seksi Informasi dan Komunikasi

Keimigrasian mengatakan bahwa dampaknya ialah:

1. Orang tidak perlu antri dari pagi

2. Tidak perlu antri lama

3. Datang sesuai dengan jadwal yang telah ditentukan, berdasarkan jam, tanggal, tempat kantor imigrasinya,

4. Cukup menyerahkan berkas-berkas yang dibutuhkan

5. Foto dan wawancara dengan cepat, setelah itu pulang

Dampak negatif yang ditimbulkan sebelum peluncuran aplikasi APAPO, ialah:

1. Semua dilakukan secara manual

2. Orang datang untuk antri pagi-pagi sekali, untuk mendapatkan nomor antrian

3. Menunggu antrian lama untuk foto

Kendala yang dihadapi oleh pihak keimigrasian dalam peluncuran aplikasi APAPO, sejauh ini tidak ada kendala yang dihadapi. Justru beliau mengatakan bahwa dengan adanya aplikais ini sangat membantuk pihak imigrasi dan beliau juga mengatakan dengan adanya aplikasi ini juga membuat masyarakat lebih tertib dalam mengajukan permohan paspor. Pemohon juga tidak perlu berlama-lama di kantor imigrasi, dimana dalam hal ini banyak orang yang sibuk dalam pekerjaannya dan tidak sempat untuk dapat datang langsung ke pihak kantor. Mereka yang ingin mengajukan permohonan paspor dan ada kendala pekerjaan mereka juga tidak perlu bolos dalam pekerjaannya, mereka hanya perlu duduk manis dan membuka aplikasi APAPO di gadget mereka. Untuk yang sekolah pun tidak perlu repot-repot datang ke kantor imigrasi tapi mereka juga dapat mendownload aplikasinya bahkan juga dapat mengakses lewat websitenya.

Strategi Reformasi Birokrasi di Kantor Imigrasi Kelas I Malang di dasarkan pada 8 area perubahan Reformasi Birokrasi Kementrian Hukum dan HAM yaitu sebagai berikut: 1)Bimbingan Rohani, Fasilitas Olahraga, dan Medical Check Up dalam rangka memperbaiki mental aparatur, 2)Aplikasi SIMPEG dan keterbukaan informasi pelaporan untuk mengawasi kinerja pegawai, 3)Program SIMPONI dan keterbukaan biaya pembuatan paspor dalam upaya meningkatkan akuntabilitas, 4)kejelasan tugas dan fungsi untuk meningkatkan fungsi kelembagaan, 5)Perubahan tata laksana dalam pengurusan paspor dengan memangkas birokrasi, 6)Diklat dan rapat internal untuk meningkatkan kualitas sumber daya manusia aparatur sipil negara, 7)Diskresi sebagai implementasi peraturan perundang-undangan, 8)Peningkatan kualitas pelayanan publik melalui penerapan pasport delivery, dan weekend pasport service. Dapat dilihat dipoint ke 8 strategi Reformasi Birokrasi yaitu peningkatan kualitas pelayanan publik salah satunya di Kota Malang menggunakan Aplikasi yang bernama APAPO.

Pelaksanaan reformasi birokrasi ditinjau dari Sasaran Road Map Reformasi Birokrasi 2015-2019 dalam pelayanan publik yang dilakukan Kantor Imigrasi Kelas I Malang telah memenuhi aspek dari arah kebijakan sasaran reformasi birokrasi yaitu: birokrasi yang bersih dan akuntabel, birokrasi yang efektif dan efisien, dan birokrasi yang memiliki pelayanan publik berkualitas. Faktor pendukung program yaitu 
aparatur yang produktif, kebijakan yang representatif, dan peningkatan kapasitas pegawai. Faktor penghambat program yaitu minimnya sarana dan prasarana, sumber daya manusia yang tidak mengerti teknologi, dan perilaku buruk oknum pegawai.

Fungsi utama pemerintah ialah melayani rakyatnya. Adanya pelayanan publik tidak terlepas dari tugas pemerintah sebagai pelayan. Pelayan publik dapat didefinisikan sebagai upaya pemenuhan kebutuhan maupun keinginan masyarakat oleh para penyelenggara negara. Pada masa kini pelayanan yang diberikan bermacam-macam. Adapun yang berbasis teknologi dikarenakan Indonesia sedang dalam proses pembentukan E-government. Dalam pelayanan untuk pembutan paspor secara online maupun manual telah di berikan keringanan Untuk kelompok rentan ( lansia 60 tahun keatas, ibu hamil, \& difabel) dibebaskan antrian online s/d pukul 10.00 WIB. Hal ini dikarenakan beberapa faktor yang mungkin bisa mempengaruhi kondisi mereka dalam melakukan proses antrian. Dimana dalam hal ini proses antrian yang lama dan memakan waktu yang sangat panjang. Mereka diberikan pelayanan khusus agar tidak terjadi penyiksaan dalam hal untuk mengantri. Dalam pelayanan publik diperlukan komunikasi antar kedua belah pihak antara pelaksana dan penyelenggara.

Komunikasi memiliki peranan sangat penting karena merupakan bentuk koordinasi antar anggota atau tim untuk menyampaikan ide dan gagasan. Dalam hal ini masyarakat sudah banyak mengetahui bahwasannya pihak Kantor Imigrasi Kota Malang telah meluncurkan sebuah penemuan baru yaitu Aplikasi APAPO yang dijamin akan membawa dampak dampak baik bagi masyarakat yang hendak membuat paspor tanpa antri lama. Melihat dari kuota yang telah ditetapkan, selalu penuh dan pengecekan yang dilakukan 2 minggu sekali setiap hari Jumat dan dibukanya aplikasi ini setiap hari Senin-Selasa.

Sumber daya manusia di Kantor Imigrasi Kota Malang ini hanya mampu memproses 150200 orang setiap harinya. Akan tetapi, masyarakat yang datang selalu lebih dari jumlah kuota yang telah ditetapkan. Kemampuan SDM pelayanan di Kantor Imigrasi Kota Malang ini hanya mampu memproses pemohon sejumlah 150-200 orang setiap harinya. Akan tetapi, masyarakat yang tidak mendapatkan tempat di kuota tersebut selalu meminta untuk tetap dilayani. Jikalau hal ini dipaksakan, maka petugas bisabisa tidak bisa pulang.

Sikap yang diperlakukan petugas imigrasi sangat baik, dimana mereka akan memberi pelayanan lebih kepada pemohon yang menyandang disabilitas, ibu hamil dan lansia (diatas 60 tahun), dimana mereka harus lebih ekstra protectif agar dalam melakukan antrian mereka tidak sampai kelelahan. Pihak imigrasi mendahulukan mereka karena dalam hal ini kesehatan mereka sangat berpengaruh dalam proses antrian nanti. Dimana mereka akan diberikan pelayanan dengan bebas antri online untuk mendapatkan paspor dan langsung dilayani dengan sigap dan cepat dalam pemrosesannya.

\section{SIMPULAN}

Pengimplementasian e-goverment di Kantor Imigrasi Malang berupa paspor online dapat dikatakan efektif dan memnuhi standart kualitas pelayanan yang baik di dalam memberikan pelayanan. Mengenai prosedur pelayanan sudah sederhana dan dapat dipahami oleh masyarakat, kedisplinan pegawai yang semakin baik, pegawai tanggap dalam melayani. Dengan adanya aplikasi paspor online APOPO, proses pembuatan paspor saat ini menjadi lebih mudah, murah, dan cepat. Hal ini dikarenakan pemohon dapat mengurusnya sendiri tanpa bantuan dari orangorang yang dengan sengaja mengambil keuntungan sendiri (dalam hal ini calo-calo yang banyak berkeliaran di sekitar lingkungan kantor imigrasi ataupun birojasa). Hal ini merupakan salah satu bentuk nyata dari berkembangnya $e$ goverment khususnya dibidang pelayanan publik yang secara langsung dapat dirasakan oleh warga negara khususnya di wilayah Malang.

\section{DAFTAR RUJUKAN}

Angguna, Y. 2015. Upaya Pengembangan EGovernment dalam Pelayanan Publik pada Dinas Koperasi dan UKM Kota Malang. Jurnal Administrasi Publik, 3, 80-88. 
Atthahara, H. 2018. Inovasi Pelayanan Publik Berbasis E-Government/ : Studi Kasus Aplikasi Ogan Lopian Dinas Komunikasi dan Informatika di Kabupaten Purwakarta. Jurnal Politik Indonesia. 3, 66-77.

Bintari, S. C., Zenju, H. N. S. \& Purnamasari, I. 2017. Kelas I Kota Bogor Quality of Service in the Office of Immigration Passport Making Class I Kota Bogor. Jurnal Governansi 3, 41-52.

Deshinta, W. S. 2017. Fungsi Pengawasan Keimigrasian dalam Pengendalian Radikalisme Pasca Penerapan Kebijakan Bebas Visa Kunjungan. 15-28.

Firdaus, I. 2018. Optimalisasi Pos Lintas Batas Tradisional dalam Pelaksanaan Fungsi Keimigrasian Studi Kasus Imigrasi Entikong. Jurnal Ilmu Kebijakan Hukum, 12, 57.

Jayanti, N. K. D. A. 2018. Kajian Analisa: Penerapan dan Pengembangan eGovernment pada Pemerintah Propinsi Bali. Creat. Inf. Technol. J. 4, 14.

Juliarso, A. 2019. Analisis Implementasi EGovernment Dalam Pemerintah Daerah Kabupaten Ciamis. 10.

Noveriyanto, B., Nisa, L. C., Bahtiar, A. S., Sahri, S. \& Irwansyah, I. 2018. E-
Government sebagai layanan komunikasi pemerintah Kota Surabaya (Studi Kematangan e-government Sebagai Layanan Komunikasi Government to Government, Government to Citizen, Government to Business). Profetik, 11, 37. Nugraha, J. T. 2018. E-Government Dan Pelayanan Publik (Studi Tentang Elemen Sukses Pengembangan E-Government Di Pemerintah Kabupaten Sleman). Jurnal Komunikasi dan Kajian Media 2, 3242.

Ramdhani, A. \& Ramdhani, M. A. 2017. Konsep Umum Pelaksanaan Kebijakan Publik. Jurnal Publik 1-12.

Sari, K. D. A. \& Winarno, W. A. 2012. Implementasi E-Goverment System Dalam Upaya Peningkatan Clean And Good Goverment di Indonesia. Jeam, XI, 1-19.

Waruwu, H. \& Masitho, B. 2016. Efektivitas Pelayanan Paspor Pada Kantor Imigrasi Kelas I Khusus Medan. JurnalAdministrasi Publik 4, 43-51.

Wiralestari \& Fredy. 2018. Kapasitas Sumber Daya Manusia dan Proses Pelayanan Publik Terhadap Pemanfaatan E_Government. Jurnal Akuntansi. 3, $1-8$. 